\section{児童生徒の都市と㯺林に於ける発育について （東京都と鳥取県の場合）}

\section{鳥取大学○川 本 萬 尋}

都市と農村と云う立場から東京都と鳥取県つ小中学生 の体格の身長, 体重, 胸囲, 座高の面について両考を比 較し乍ら，昭和 30 年度から 40 年度に至る約 10 ケ年润 の変化を見たのであるが，概要をあげれば次の通りであ る.

1. 東京都の小中学生は男女共濃村地带の鳥取罚よ りも発育が非常に艮く可成りの差異を有する。

2. 発育経過は，（イ）体重は他の部位に比し作作に 都市は農村より增大しつつある.（口）胸国は眆和 32,3 年頃まで農村地带の鳥取県が優位であつたものが近什東 京都が優位に立ちその差恃增大しつつある。（八）農村 地带の鳥取県の女子のみは発亩全体が罗子に比し进好之 なりつつある。

3. 30 年度より 5 年後の 35 年度， 10 年後の 40 年度 の発吉は鳥取上りも東京の方が男女共に后好で，仰阔の 発有量は都市農村共に 30 年度よりも10 作後の 40 作度 の方が東京・鳥取共によいが都市が優位に立ち，発行の ピーク時の量は 30 个度の方が両才j共によいが女子の発
奆に限り農村がよい部位がある。

4. 身長に対する比は体重のみは男女並に都市農村共 に順次增大を示し，その数は都市山大きく胸团は 30 年 度より低調である。

5. 発育期については男女の 発育曲線の 交錯期が 10 作開の闑に1才位早くなつている上に最大発育をする年 令がやはり1才早くなつている本等の束蛪から，発育期 が1才位早くなり謂所の早期発育するのではないか、こ れは都市農村共京様の傾问を示寸が多少都市が早いので はないかと思はれる。

要するに，体格は都市の子供が優位である，增大量は 近年のカが優位である.

農村地带の女子注男子に比し発有は趾好となりつつあ る.

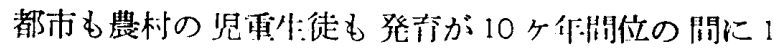

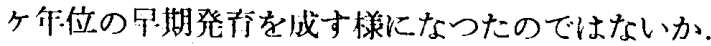

休格の発青は多く栄㿥に原肉していると云はれるので 都市農村の栄䗝つ撮取量の美が多くの原风であろうが，

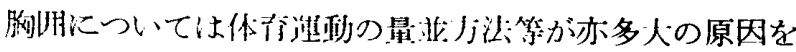
なしていると思われる。

\section{発育の加速化現魚に関する研究}

\section{一生年別発充の推移について一}

静阔大学○渡边

功, 勝又 五郎

梅沢 トシ，斎藤千代子

I. はじめに 発育に関する研究は厸くなされてお。 り，特に近作加速化の問題が世界各国の共通点として注: 日されている。静岡県でも児童生徒の発青は向上してき ている反面，細長型の傾向を示寸点が指摘されている. そこで県児童生徒の生年别発育の推移を全国と比較し社 会的背景との関連も考察し，保健体有指導上の手がかり を得るために研究した。

\section{II. 瓷料及ひ模討の方法 I . (1) 県教委に上る} 炤和 4〜39 作，6１6，17 才の男女別発育資料．（2）炤 和 39 年度文部省の学校保健統計資料．2１．の資料から 比較的整つた年次を生年別に身長・体重・胸囲について その推移を考察した。

III. 研究の結果及び考察 1，年阔発育增加量の 最人時期と乞の量をみると，明治 27 年生淿比し大正 10 年生は早期化の傾向を示し，昭和 15 作生は後退，畹和 20 -25 年生は再び 是期化してきている，增加量につい ては，明治 27 年生より增しているが，その後は盖程て はない，2．小・中・高期の 発逳 增加量を（1）明治 27
年生と比較すると，身長は全・旼・男女とも小学校期が 一番伸びているが，女子は特に著しい，休重は男子は中

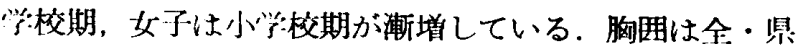
・男女とも体重とほぼ同じ傾向を示す（2）小・中・高 期の增加量を 1 ケ年閏に平约してその伸びをみると，身 長は男子中学校期の平均增加量が大きく，女子は小・中 校期の閶に差はなく，高校期が立つて低い，休禹は男 子小校期の平壮增加量が巾・高期に比して少ない，女子 は中校期が最も高い，胸用は全・県・男女とも体重と同 傾㘬を示す．3．明治 27 年生との発育量を比較すると， 身長は昭和 25 年牛が特にその伸びが著しく，体重・胸 囲についても急增していろが，県の場命江男女とも令国 上り下まわつている，4，ローレル指数の推移をみると，

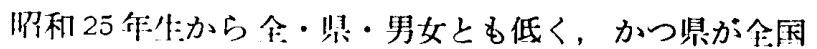
よりその数値が低くなつている.

IV. 楼括と反省 今回の研究の結果から, 発育の 加速化見象を生年別に考察したが，全国も県子年次别に， 叝告されたものと一般的に同様の結果がみられた，発付 の增加量に打いては近年県は全国上り体重・胸囲が少り 細長型の傾向が琶められた。な挆社会的背景については 期待した結果が得られず今後の䂺題としたい， 